\title{
Efek Antioksidan dari C-Fikosianin pada Spirulina
}

\author{
Henoch W. Burhan, ${ }^{1}$ Yanti M. Mewo, ${ }^{2}$ Youla A. Assa ${ }^{2}$
}

\author{
${ }^{1}$ Program Studi Pendidikan Dokter Fakultas Kedokteran Universitas Sam Ratulangi \\ Manado, Indonesia \\ ${ }^{2}$ Bagian Biokimia Fakultas Kedokteran Universitas Sam Ratulangi Manado, Indonesia \\ Email: henochwb@gmail.com
}

\begin{abstract}
Free radicals are the products of normal cellular metabolism containing one or more unpaired electrons, which makes them highly reactive and can cause cell damage and disruption of homeostasis. Depletion of antioxidants and/or accumulation of free radicals can cause oxidative stress which plays a role in the process of various diseases such as inflammatory diseases, cancer, hemochromatosis, emphysema, hypertension and aging. Cphycocyanin is one of the main groups in phycobiliprotein and widely found in spirulina. The purpose of this study was to determine the protective effect of C-phycocyanin against free radicals. This research is in the form of literature review by searching data using two databases namely Pubmed and Google Scholar. The keywords used are C-Phycocyanin Antioxidant Effect. After being selected based on inclusion and exclusion, 10 literature was obtained for review. C-phycocyanin content in spirulina as an antioxidant can function as a defense mechanism against free radicals. In conclusion: the $\mathrm{C}$-phycocyanin content from spirulina has antioxidant effect.
\end{abstract}

Keywords: C-Phycocyanin, antioxidant effect, free radical

\begin{abstract}
Abstrak: Radikal bebas merupakan produk normal hasil metabolisme berupa molekul dengan satu atau lebih elektron yang tidak berpasangan, sehingga bersifat sangat reaktif dan dapat menyebabkan kerusakan sel dan terganggunya homeostasis. Deplesi dari antioksidan dan/atau akumulasi radikal bebas dapat menyebabkan stres oksidatif yang berperan dalam proses terjadinya berbagai penyakit seperti penyakit inflamasi, kanker, hemokromatosis, emfismea, hipertensi dan proses penuaan. C-fikosianin merupakan salah satu gugus utama dalam fikobiliprotein yang larut dalam air dan banyak terdapat dalam spirulina. Tujuan penelitian ini adalah untuk mengetahui efek proteksi C-fikosianin terhadap radikal bebas. Penelitian ini berbentuk literature review dengan pencarian data menggunakan dua database yaitu Pubmed dan Google Scholar. Kata kunci yang digunakan yaitu C-Phycocyanin Antioxidant Effect. Setelah diseleksi berdasarkan kriteria inklusi dan eksklusi, didapatkan 10 literatur untuk di review. Kandungan C-fikosianin pada spirulina sebagai antioksidan bisa berfungsi sebagai mekanisme pertahanan terhadap radikal bebas. Sebagai simpulan, kandungan C-Fikosianin dalam spirulina memiliki efek antioksidan
\end{abstract}

Kata kunci: C-fikosianin, efek antioksidan, radikal bebas

\section{PENDAHULUAN}

Radikal bebas merupakan produk normal hasil metabolisme berupa molekul dengan satu atau lebih elektron yang tidak berpasangan. ${ }^{1}$ Keberadaan elektron ini menyebabkan radikal bebas menjadi tidak stabil dan sangat reaktif. ${ }^{1,2}$ Karena sifatnya yang tidak stabil dan sangat reaktif, radikal bebas bisa bereaksi sebagai oksidan atau reduktan dan menyebabkan reaksi berantai yang berujung pada kerusakan sel dan terganggunya homeostasis. ${ }^{1,3}$ Stres oksidatif terjadi saat keseimbangan antara antioksidan dan radikal bebas/Reactive Oxygen Species (ROS) terganggu. Hal ini bisa disebabkan karena deplesi dari 
antioksidan dan/atau akumulasi radikal bebas/ROS. $^{3} \quad$ Radikal bebas dapat menyerang semua biomolekul, terutama Poly Unsaturated Fatty Acid (PUFA) pada membrane sel. ${ }^{4}$ Kerusakan oksidatif pada PUFA, dikenal dengan peroksidasi lipid dan hal ini bersifat destruktif. $^{4}$ PUFA merupakan komponen utama dari Low Density Lipoprotein (LDL), dan teroksidasinya komponen lipid dalam LDL merupakan proses yang sangat penting dalam aterosklerosis. ${ }^{2}$ Selain itu, stres oksidatif memiliki peran dalam proses terjadinya berbagai penyakit lain seperti, penyakit inflamasi (artritis, vaskulitis, glomerulonefritis), kanker, hemokromatosis, Acquired Immunodeficiency Syndrome (AIDS), emfisema, hipertensi, proses penuaan dan masih banyak lagi. ${ }^{2}$ Tubuh manusia mempunyai berbagai jenis antioksidan sebagai mekanisme pertahanan terhadap stres oksidatif. ${ }^{3}$ Antioksidan merupakan molekul yang cukup stabil untuk memberikan elektron dan menetralisir radikal bebas. ${ }^{2}$ Antioksidan bertindak sebagai pembasmi radikal bebas sehingga bisa menginhibisi kerusakan sel dan memutuskan reaksi berantai sebelum terjadi kerusakan fatal. ${ }^{2}$ Beberapa antioksidan yang bisa menetralisir radikal bebas seperti glutation dan ubikuinol diproduksi secara fisiologis pada proses metabolism, ${ }^{2}$ namun beberapa antioksidan harus diperoleh dari makanan karena tidak bisa diproduksi oleh tubuh manusia. ${ }^{2}$ Antioksidan yang terdapat dalam makanan mungkin memiliki manfaat yang lebih baik, karena antioksidan natural memiliki efek antikanker dan dapat menginhibisi reaksi oksidasi yang berbahaya secara biologis. ${ }^{5}$ Bukti epidemiologi menunjukkan bahwa antioksidan memiliki efek protektif dalam mencegah atau mengurangi keparahan yang dapat diakibatkan oleh penyakit jantung dan kanker. ${ }^{6}$ Salah satu sumber antioksidan natural adalah spirulina yang memiliki kemampuan untuk mencegah kerusakan oksidatif pada sel. ${ }^{5}$ Penelitian oleh Romay, et al pada tahun 2003 dan penelitian oleh Bhat dan Madyastha pada tahun 2000 mendemonstrasikan efek hepatoprotektif, antiinflamasi dan antioksidan dari Cfikosianin (C-PC) yang diperoleh dari spirulina platensis 7 . Penelitian oleh Park, et al pada tahun 2008 menunjukkan pemberian spirulina sebagai suplemen makanan dapat menurunkan kadar kolesterol total baik pada pria maupun wanita. ${ }^{8}$ Pada tahun 2000 Mani, et al mendemonstrasikan efek pemberian spirulina terhadap penurunan kadar total lipid darah, trigliserida dan asam lemak bebas pada sebuah studi terhadap 15 pasien diabetik. ${ }^{9}$ Kandungan antioksidan dalam spirulina secara signifikan menginhibisi peroksidasi lipid (65\%), lebih besar dibanding antioksidan kimiawi seperti $\alpha$ tokoferol $(35 \%)$, butil hidroksi toluene $(45 \%)$, dan $\beta$-karoten $(48 \%){ }^{10}$ Spirulina saat ini dipasarkan sebagai suplemen makanan karena mengandung protein, asam $\gamma$-linolenat, vitamin dan mineral 11 . Penelitian oleh Juarez-Oropeza, et al pada tahun 2009 mendemonstrasikan implikasi terapeutik spirulina terhadap penyakit kardiovaskuler seperti hipertensi. ${ }^{12}$ Pada tahun 2009 Kumari, et al melakukan penelitian terhadap efek pemberian spirulina terhadap artritis dan menunjukkan bahwa pemberian spirulina memiliki efek proteksi terhadap artritis dengan memodulasi parameter histologi dan biokimia. ${ }^{13}$ Spirulina dianggap sebagai sumber nutrisi yang paling kaya dan paling lengkap karena memiliki efek antivirus, hipolipidemik, anti diabetik dan efek antioksidan, sehingga dapat dijadikan penanganan terhadap penyakit kronik seperti diabetes dan hipertensi. ${ }^{11}$

\section{METODE PENELITIAN}

Penelitian ini berbentuk literature review yang dilakukan dengan cara identifikasi, evaluasi dan interpretasi terhadap semua hasil penelitian tertentu, topik tertentu atau fenomena yang menjadi perhatian. Literature review adalah metode penelitian yang merangkum hasil-hasil penelitian primer untuk menyajikan fakta yang lebih komprehensif dan berimbang. 


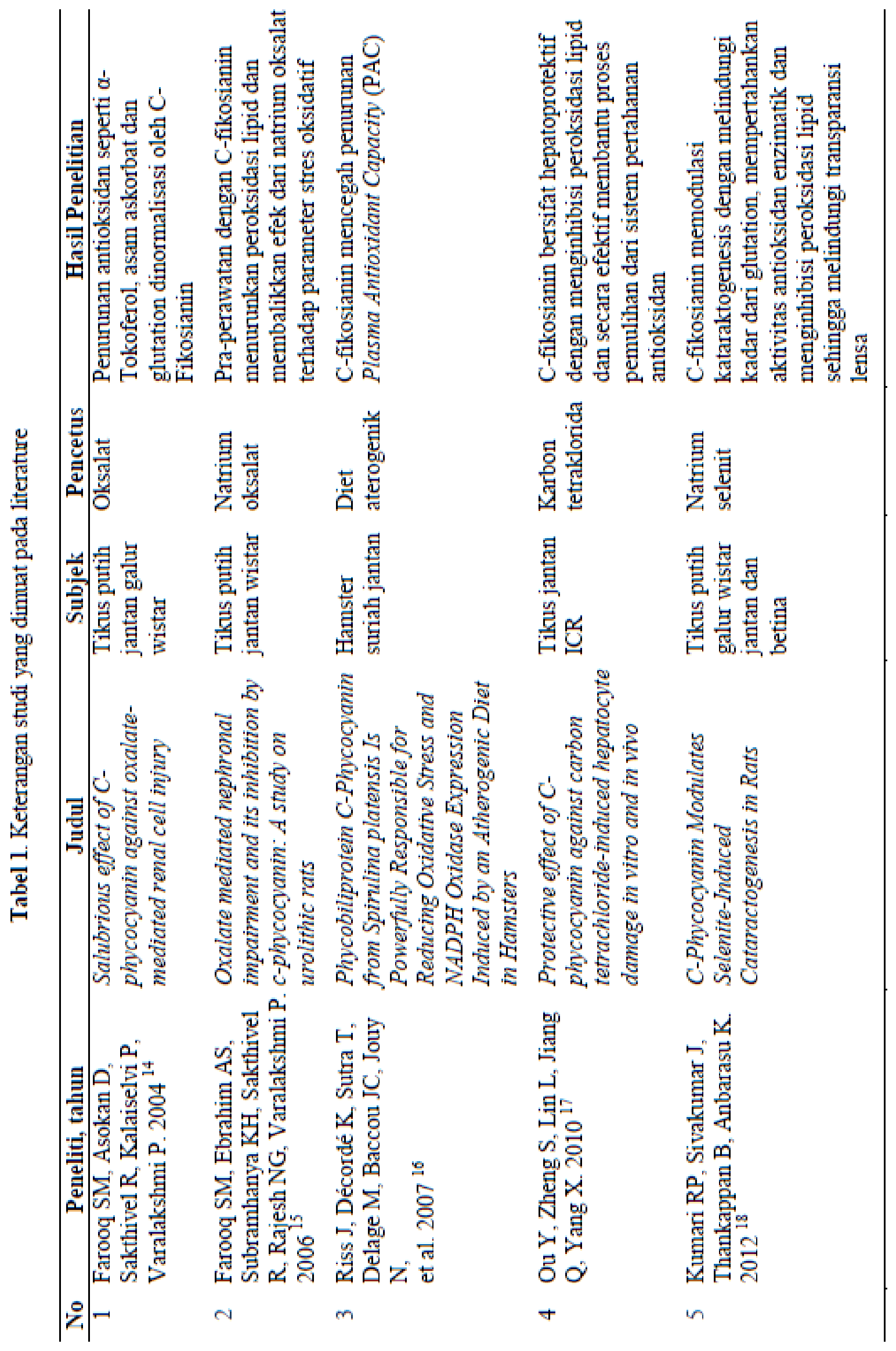




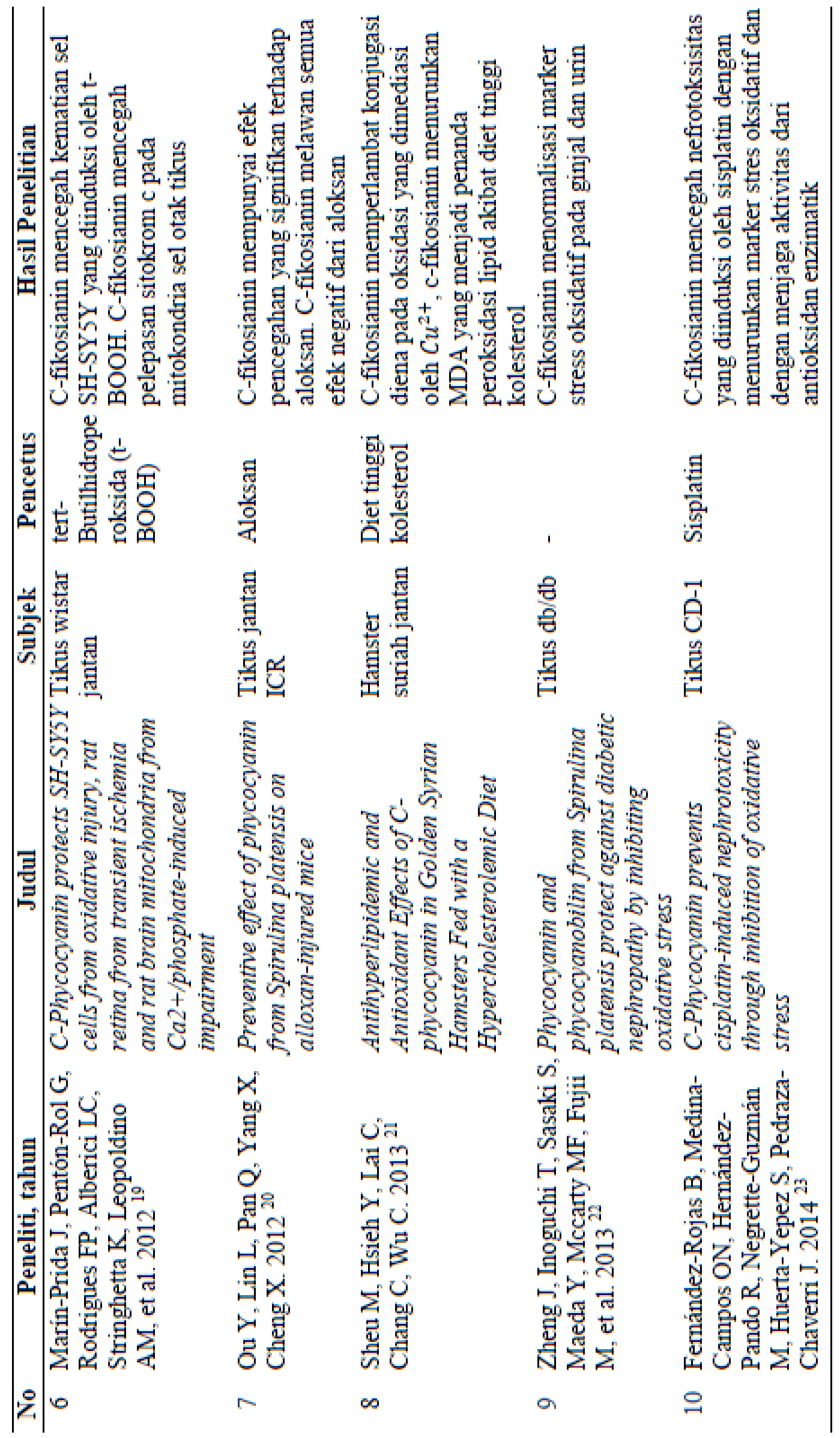


Data yang digunakan dalam penelitian ini adalah data sekunder sebagai data utama yang diperoleh bukan dari pengamatan dan data pelengkap. Data sekunder yang didapat berupa hasil penelitian, artikel atau jurnal ilmiah bereputasi baik nasional maupun internasional dengan tema yang sudah ditentukan. Pencarian data menggunakan dua database dengan kriteria yang ditentukan yaitu PubMed dan Google Scholar. Kata kunci yang digunakan dalam pencarian artkel yaitu C-Phycocyanin Spirulina Antioxidant Effect. Dari hasil pencarian dengan menggunakan kata kunci tersebut peneliti mendapatkan literatur sebanyak 73 menggunakan PubMed, 3.550 menggunakan Google Scholar $(n=3.623)$ yang sesuai dengan kata kunci tersebut. Hasil pencarian yang didapatkan kemudian dilakukan skrining berdasarkan judul yang sesuai dengan tema literature review didapatkan 50 artikel $(n=50)$. Selanjutnya artikel diskrining abstrak dan berdasarkan kriteria inklusi dan eksklusi serta duplikasi yang terdapat pada kedua database dieksklusi salah satunya secara acak didapatkan artikel $(n=10)$.

\section{HASIL PENELITIAN}

Jenis literatur yang didapatkan merupakan studi eksperimental yang dilakukan pada hewan coba seperti; tikus dan hamster. Secara keseluruhan setiap penelitian membahas tentang efek Cfikosianin terhadap radikal bebas yang akan disajikan dalam Tabel 1.

\section{BAHASAN \\ C-fikosianin menginhibisi peroksidasi lipid}

Peningkatan kerentanan membran terhadap peroksidasi lipid pada jaringan hewan coba yang diinduksi dengan oksalat mungkin berhubungan dengan menurunnya konsentrasi antioksidan seperti yang dapat dilihat pada literatur pertama oleh Farroq, et al. 2004. Peroksidasi lipid terlibat dalam patogenesis urolitiasis. Telah dibuktikan bahwa sel yang mengalami kerusakan akibat radikal bebas menjadi lingkungan yang menguntungkan untuk proses pembentukan batu ginjal. Pada literatur pertama oleh Farooq, et al. 2004 ditunjukkan bahwa efek dari C-fikosianin terhadap peroksidasi lipid berkaitan erat dengan pencegahan kerusakan jaringan akibat oksalat. ${ }^{14}$ Pada hewan coba yang diinduksi dengan natrium oksalat, terjadi penurunan antioksidan molekul kecil seperti $\alpha$-tokoferol, vitamin $\mathrm{C}$ dan glutation. Ketiga antioksidan ini saling terkait satu dengan yang lain dalam proses daur ulang. Proses daur ulang tokoferol dapat tercapai dengan reaksi dari vitamin c, dari proses tersebut terbentuk asam dehidroaskorbat yang akan direduksi oleh glutation dalam reaksi non-enzimatik. Penurunan dari ketiga antioksidan ini akan menghasilkan peningkatan dalam reaksi peroksidasi lipid. Hal ini menjelaskan mengapa terjadi peroksidasi lipid dan penurunan antioksidan molekul kecil pada hewan hiperoksaluria. Pemberian Cfikosianin dapat menormalkan parameter diatas, menunjukkan potensi antioksidan terhadap radikal bebas yang diinduksi oksalat. $^{14}$

Malondialdehid (MDA) merupakan produk sampingan dari peroksidasi lipid dan diukur sebagai indikator kerusakan oksidatif. Dapat dilihat dari hasil penelitian literatur kedua (Farooq, et al. 2006) di mana kadar MDA yang tinggi hanya terlihat pada kelompok hewan coba urolitik, sementara kadar MDA pada kelompok hewan coba yang diberikan Cfikosianin terkontrol, yang menunjukkan potensi kemampuan Cfikosianin untuk meminimalisir kerusakan akibat radikal bebas dengan bereaksi dengan radikal hidroksil sehingga menekan peroksidasi lipid. ${ }^{15}$ Seperti yang dapat dilihat pada literatur ketiga oleh Riss, et al. 2007 di mana Cfikosianin mencegah progresi dari atersoklerosis pada hewan coba dengan diet kolesterol yang tinggi dengan menginhibisi peroksidasi lipid dan meningkatkan aktivitas dari mekansime pertahanan antioksidan pada plasma lipoprotein. ${ }^{16} \mathrm{Hal}$ yang sama dapat diamati pada penelitian oleh $\mathrm{Ou}$, et al. 2010 di mana peroksidasi lipid merupakan salah satu penyebab 
kerusakan yang diinduksi oleh karbon tetraklorida. Peningkatan MDA pada liver menunjukkan adanya kerusakan jaringan dan penurunan aktivitas antioksidan sehingga terjadi pembentukan radikal bebas yang lebih banyak lagi. Pada literatur keempat oleh $\mathrm{Ou}$, et al. pada tahun 2010, C-fikosianin menunjukkan penurunan yang signifikan pada kadar MDA yang menunujukkan bahwa C-fikosianin bisa menjadi mekanisme pertahanan terhadap peroksidasi lipid yang diinduksi oleh karbon tetraklorida. Efek proteksi hepar dari C-fikosianin mungkin berhubungan dengan kemampuan C-fikosianin menginhibisi peroksidasi lipid dan mengembalikan fungsi antioksidan dalam tubuh yang mengalami penurunan akibat radikal bebas yang diinduksi oleh karbon tetraklorida. ${ }^{17}$ Peroksidasi lipid akibat radikal bebas merupakan mekanisme yang penting dalam terjadinya kekeruhan pada lensa dan kataraktogenesis, seperti yang dapat dilihat pada penelitian oleh Kumari, et al. 2012, di mana terdapat peningkatan MDA yang dapat diamati pada kelompok hewan coba yang terekspos dengan selenit jika dibandingkan dengan kelompok hewan coba yang diberikan perawatan Cfikosianin. Hasil ini memberikan kesan Cfikosianin dapat mencegah terjadinya peroksidasi lipid yang diakibatkan oleh natrium selenit. ${ }^{18}$

\section{C-fikosianin meningkatkan aktivitas antioksidan}

Mekanisme lainnya dari C-fikosianin dalam melawan stres oksidatif adalah dengan meningkatkan kembali kadar GSH, CAT dan glukosa-6-fosfatdehidrogenase (G6PD). Glutation berperan dalam melindungi sel dari kerusakan oksidatif dan dalam meningkatkan aktivitas dari antioksidan seperti vitamin $\mathrm{C}$ dan vitamin E, sehingga jika GSH menurun akan terjadi kerusakan sel dan penurunan imunitas akibat aktivitas dari antioksidan yang berkurang. Pada penelitian oleh Farooq, et al. pada tahun 2006, kelompok hewan coba yang diberikan C-fikosianin, kadar glutation tidak mengalami penurunan walaupun diinduksi dengan oksalat yang menunjukkan efek antioksidan dari Cfikosianin cukup ampuh untuk menetralisir efek toksik dari oksalat pada sel. ${ }^{15}$ Pada litereatur dengan judul CPhycocyanin prevents cisplatin-induced nephrotoxicity through inhibition of oxidative stress oleh Fernández-Rojas, et al. pada tahun 2014, sisplatin menurunkan aktivitas antioksidan enzimatik seperti GSHPx, GST, CAT dan GR sebesar 40\%, $23 \%, 40 \%$ dan $11 \%$ pada kelompok hewan coba. C-fikosianin mencegah penurunan aktivitas antioksidan enzimatik yang diinduksi oleh sisplatin, yang menunjukkan efek proteksi renal dari C-fikosianin adalah dengan memelihara aktivitas antioksidan enzimatik. $^{23}$

\section{Efek antioksidan C-fikosianin terhadap diabetes melitus}

Aloksan sering digunakan pada studi eksperimental diabetes. Aloksan menginduksi diabetes dengan merusak sel $\beta$ pada pankreas dan menginduksi radikal bebas, khususnya superoksida yang menyebabkan kerusakan progresif dan berujung pada kematian sel $\beta$ dan hipoinsulinemia sehingga terjadi penurunan penggunaan glukosa pada jaringan. Pada penelitian $\mathrm{Ou}$, et al. 2012, C-fikosianin menunjukkan penurunan kadar gula darah puasa dengan melindungi sel $\beta$ pankreas dari kerusakan yang diakibatkan oleh aloksan dan mempromosikan regenerasi dari sel $\beta 20$. Diabetes melitus menyebabkan stres oksidatif yang menyebabkan kerusakan oksidatif pada liver, ginjal dan pankreas. Sistem pertahanan antioksidan yang melemah mempromosikan pembentukan radikal bebas. Pada diabetes melitus, terjadi penurunan antioksidan dan peningkatan peroksidasi lipid. Pada penelitian $\mathrm{Ou}$, et al. 2012, telah dikonfirmasi bahwa terdapat korelasi yang kuat antara stres oksidatif dan kejadian diabetes melitus, dan pemberian C-fikosianin bermanfaat dalam menangani diabetes mellitus. ${ }^{20}$ Penelitian dalam bentuk literature review ini memiliki kelebihan dan kekurangan. Kelebihan dalam penelitian ini adalah penelitian ini dapat dijadikan 
sebagai dasar untuk dilakukan penelitian lebih lanjut mengingat masih sedikit penelitian mengenai efek antioksidan dari C-fikosianin di Indonesia. Kekurangan penelitian ini adalah pemilihan subjek yang hanya dilakukan pada hewan coba dan tidak pada manusia dan sedikitnya literatur yang direview karena hanya menggunakan dua database saja sebagai sumber literatur serta adanya keterbatasan waktu dalam melakukan penelitian.

\section{SIMPULAN}

Berdasarkan penelitian yang dilakukan secara literature review, maka dapat disimpulkan bahwa kandungan Cfikosianin pada spirulina memiliki efek antioksidan.

\section{Konflik Kepentingan}

Penulis menyatakan tidak terdapat konflik kepentingan dalam studi ini.

\section{DAFTAR PUSTAKA}

1. Phaniendra A, Jestadi DB, Periyasamy L. Free Radicals: Properties, Sources, Targets, and Their Implication in Various Diseases. Indian J Clin Biochem. 2015;30(1):11-26.

2. Lobo V, Patil A, Phatak A, Chandra N. Free radicals, antioxidants and functional foods: Impact on human health. Pharmacogn Rev. 2010;4(8):118-26.

3. Leverve $X$. Oxidative, stress and antioxidants? Cah Nutr Diet. 2009;44(5):219-24.

4. Nimse SB, Pal D. Free radicals, natural antioxidants, and their reaction mechanisms. Vol. 5, RSC Advances. 2015. 27986-28006 p.

5. Zhou ZP, Liu LN, Chen XL, Wang JX, Chen M, Zhang YZ, et al. Factors that effect antioxidant activity of cphycocyanins from spirulina platensis. J Food Biochem. 2005;29(3):313-22.

6. Gad AS, Khadrawy YA, El-Nekeety AA, Mohamed SR, Hassan NS, AbdelWahhab MA. Antioxidant activity and hepatoprotective effects of whey protein and Spirulina in rats. Nutrition 2011;27(5):582-9.
7. Moraes CC, Sala L, Cerveira GP, Kalil SJ. C-Phycocyanin extraction from Spirulina platensis wet biomass. Brazilian J Chem Eng. 2011;28(1):45-9.

8. Park HJ, Lee YJ, Ryu HK, Kim MH, Chung HW, Kim WY. A randomized double-blind, placebo-controlled study to establish the effects of spirulina in elderly Koreans. Ann Nutr Metab. 2008;52(4):322-8.

9. Mani UV, Desai S, Iyer U. Studies on the Long-Term Effect of Spirulina Supplementation on Serum Lipid Profile and Glycated Proteins in NIDDM Patients. Journal of Nutraceuticals, Functional \& Medical Foods 2000;2(3):25-32

10. Benedetti S, Benvenuti F, Pagliarani S, Francogli S, Scoglio S, Canestrari F. Antioxidant properties of a novel phycocyanin extract from the bluegreen alga Aphanizomenon flosaquae. Life Sci. 2004;75(19):235362.

11. Joventino IP, Alves HGR, Neves LC, Pinheiro-Joventino F, Leal LKAM, Neves SA, et al. The microalga Spirulina platensis presents antiinflammatory action as well as hypoglycemic and hypolipidemic properties in diabetic rats. $\mathrm{J}$ Complement Integr Med. 2012;9(1).

12. Juárez-Oropeza MA, Mascher D, TorresDurán P V., Farias JM, ParedesCarbajal MC. Effects of dietary spirulina on vascular reactivity. J Med Food. 2009;12(1):15-20.

13. Kumar N, Singh S, Patro N, Patro I. Evaluation of protective efficacy of Spirulina platensis against collageninduced arthritis in rats. Inflammopharmacology. 2009;17(3):181-90.

14. Farooq SM, Asokan D, Sakthivel R, Kalaiselvi P, Varalakshmi P. Salubrious effect of C-phycocyanin against oxalate-mediated renal cell injury. Clin Chim Acta. 2004;348(12):199-205.

15. Farooq SM, Ebrahim AS, Subramhanya $\mathrm{KH}$, Sakthivel R, Rajesh NG, Varalakshmi P. Oxalate mediated 
nephronal impairment and its inhibition by c-phycocyanin: A study on urolithic rats. Mol Cell Biochem. 2006;284(1-2):95-101.

16. Riss J, Décordé K, Sutra T, Delage M, Baccou JC, Jouy N, et al. Phycobiliprotein C-phycocyanin from Spirulina platensis is powerfully responsible for reducing oxidative stress and NADPH oxidase expression induced by an atherogenic diet in hamsters. J Agric Food Chem. 2007;55(19):7962-7.

17. Ou Y, Zheng S, Lin L, Jiang Q, Yang X. Protective effect of C-phycocyanin against carbon tetrachloride-induced hepatocyte damage in vitro and in vivo. Chem Biol Interact 2010;185 (2):94-100.

18. Kumari RP, Sivakumar J, Thankappan B, Anbarasu K. C-phycocyanin modulates selenite-induced cataractogenesis in rats. Biol Trace Elem Res. 2013;151(1):59-67.

19. Marín-Prida J, Pentón-Rol G, Rodrigues FP, Alberici LC, Stringhetta K, Leopoldino AM, et al. CPhycocyanin protects SH-SY5Y cells from oxidative injury, rat retina from transient ischemia and rat brain mitochondria from $\mathrm{Ca} 2+/$ phosphate- induced impairment. Brain Res Bull 2012;89(5-6):159-67.

20. Ou Y, Lin L, Pan Q, Yang X, Cheng X. Preventive effect of phycocyanin from Spirulina platensis on alloxaninjured mice. Environ Toxicol Pharmacol. 2012;34(3):721-6.

21. Sheu M, Hsieh Y, Lai C, Chang C, Wu C. Antihyperlipidemic and Antioxidant Effects of C-phycocyanin in Golden Syrian Hamsters Fed with a Hypercholesterolemic Diet Animal preparation. J Tradit Complement Med 2013;3(1):41-7.

22. Zheng J, Inoguchi T, Sasaki S, Maeda Y, Mccarty MF, Fujii M, et al. Phycocyanin and phycocyanobilin from spirulina platensis protect against diabetic nephropathy by inhibiting oxidative stress. Am J Physiol - Regul Integr Comp Physiol. 2013;304(2):110-20.

23. Fernández-Rojas B, Medina-Campos ON, Hernández-Pando R, NegretteGuzmán M, Huerta-Yepez S, Pedraza-Chaverri J. C-Phycocyanin prevents cisplatin-induced nephrotoxicity through inhibition of oxidative stress. Food Funct. 2014; 5(3):480-90. 